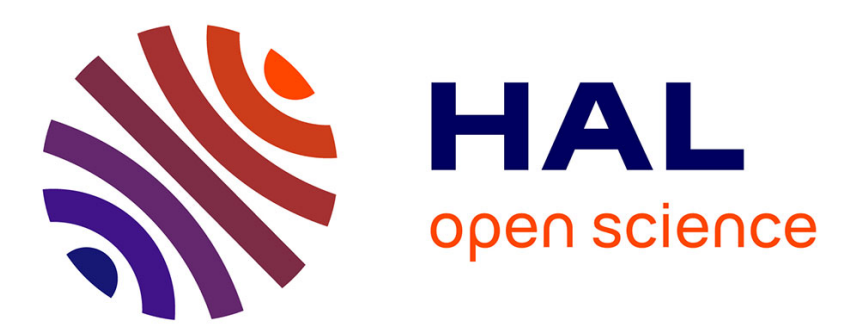

\title{
Metal immobilization by sludge-derived biochar: roles of mineral oxides and carbonized organic compartment
} Weihua Zhang, Xinchen Huang, Yanming Jia, Frédéric Rees, Daniel C. W. Tsang, Rongliang Qiu, Hong Wang

\section{- To cite this version:}

Weihua Zhang, Xinchen Huang, Yanming Jia, Frédéric Rees, Daniel C. W. Tsang, et al.. Metal immobilization by sludge-derived biochar: roles of mineral oxides and carbonized organic compartment. Environmental Geochemistry and Health, 2016, 39 (Environ Geocherm Health), 10.1007/s10653-0169851-z . hal-01458427

\author{
HAL Id: hal-01458427 \\ https://hal.science/hal-01458427
}

Submitted on 6 Feb 2017

HAL is a multi-disciplinary open access archive for the deposit and dissemination of scientific research documents, whether they are published or not. The documents may come from teaching and research institutions in France or abroad, or from public or private research centers.
L'archive ouverte pluridisciplinaire HAL, est destinée au dépôt et à la diffusion de documents scientifiques de niveau recherche, publiés ou non, émanant des établissements d'enseignement et de recherche français ou étrangers, des laboratoires publics ou privés. 


\title{
Metal immobilization by sludge-derived biochar: roles of mineral oxides and carbonized organic compartment
}

\author{
Weihua Zhang - Xinchen Huang • Yanming Jia • \\ Frederic Rees • Daniel C. W. Tsang • Rongliang Qiu • \\ Hong Wang
}

Received: 25 January 2016/ Accepted: 5 July 2016

(C) Springer Science+Business Media Dordrecht 2016

\begin{abstract}
Pyrolyzing sludge into biochar is a potentially promising recycling/disposal solution for municipal wastewater sludge, and the sludge-derived biochar (SDBC) presents an excellent sorbent for metal immobilization. As SDBC is composed of both mineral oxides and carbonized organic compartment, this study therefore compared the sorption behaviour of $\mathrm{Pb}$ and $\mathrm{Zn}$ on SDBC to those of individual and mixture of activated carbon (AC) and amorphous aluminium oxide $\left(\mathrm{Al}_{2} \mathrm{O}_{3}\right)$. Batch experiments were conducted at 25 and $45{ }^{\circ} \mathrm{C}$, and the metal-loaded
\end{abstract}

Electronic supplementary material The online version of this article (doi:10.1007/s10653-016-9851-z) contains supplementary material, which is available to authorized users.

W. Zhang $\cdot$ X. Huang $\cdot$ Y. Jia $\cdot$ R. Qiu

School of Environmental Science and Engineering, Sun

Yat-sen University, Guangzhou 510275, China

W. Zhang · R. Qiu

Guangdong Provincial Key Laboratory of Environmental

Pollution Control and Remediation Technology,

Guangzhou 510275, China

F. Rees

Laboratoire Sols et Environnement, UMR 1120,

Université de Lorraine, 2, avenue de la Forêt de Haye,

TSA 40602, 54518 Vandoeuvre-lès-Nancy cedex, France

F. Rees

Laboratoire Sols et Environnement, UMR 1120, INRA, 2, avenue de la Forêt de Haye, TSA 40602,

54518 Vandoeuvre-lès-Nancy cedex, France sorbents were artificially aged in the atmosphere for 1-60 days followed by additional sorption experiments. The $\mathrm{Pb}$ sorption was generally higher than $\mathrm{Zn}$ sorption, and the co-presence of $\mathrm{Pb}$ reduced $\mathrm{Zn}$ sorption on each studied sorbent. Higher sorption capacities were observed at $45^{\circ} \mathrm{C}$ than $25^{\circ} \mathrm{C}$ for SDBC and $\mathrm{AC}$, while the opposite was shown for $\mathrm{Al}_{2} \mathrm{O}_{3}$, indicating the significance of temperaturedependent diffusion processes in SDBC and AC. Nevertheless, metal sorption was more selective on $\mathrm{Al}_{2} \mathrm{O}_{3}$ that showed a greater affinity towards $\mathrm{Pb}$ over $\mathrm{Zn}$ under competition, correlating with the reducible fraction of sequential extraction. Furthermore, significant amounts of $\mathrm{Pb}$ and $\mathrm{Zn}$ were additionally sorbed

\author{
D. C. W. Tsang \\ Department of Civil and Environmental Engineering, \\ Hong Kong Polytechnic University, \\ Hung Hom, Kowloon, Hong Kong, China \\ H. Wang $(\bowtie)$ \\ School of Environmental Science and Engineering, \\ Southern University of Science and Technology, \\ Shenzhen 518055, China \\ e-mail: wangh6@mail.sustc.edu.cn
}


on SDBC following 30-day ageing. The X-ray diffraction revealed the formation of metal-phosphate precipitates, while the X-ray photoelectron spectroscopy showed a larger quantity of metal-oxygen bonding after 30-day ageing of metal-loaded SDBC. The results may imply favourable long-term transformation and additional sorption capacity of SDBC. In conclusion, SDBC resembles the sorption characteristics of both organic and mineral sorbents in different aspects, presenting an appropriate material for metal immobilization during soil amendment.

Keywords Metal sorption - Sludge-derived biochar . Mineral oxides $\cdot$ Activated carbons

\section{Introduction}

Compared to direct application of dewatered sludge in farmland, pyrolyzing sewage sludge into biochar is considered as a potentially excellent strategy for sludge recycling/disposal and carbon subtraction (Liu et al. 2014; Song et al. 2014; Wesenbeeck et al. 2014; Kuppusamy et al. 2016). More importantly, the sludge-derived biochar (SDBC) have been found capable of immobilizing different kinds of heavy metal species such as cationic $\mathrm{Pb} / \mathrm{Zn}$ and oxy-anionic $\mathrm{Cr}(\mathrm{VI}) / \mathrm{As}(\mathrm{III})$ (Lu et al. 2012; Zhang et al. 2013, 2015; Inyang et al. 2016). Contrary to the biochars produced from plant residues (e.g. raw straw and wood strips, Chen et al. 2012) and animal manure (e.g. cattle manure and poultry manure, Cao and Harris 2010), SDBC contains a lower content of organic carbon but a higher content of mineral oxides (Zhang et al. 2013).

The mineral oxides originate from colloids in municipal wastewater are entrapped in sewage sludge, especially when primary sedimentation tank is absent from wastewater treatment process due to the low chemical oxygen demand of the wastewater. These colloids are natural soil components and mainly present as amorphous mineral oxides, thus presenting the bulk of active sites of SDBC. A number of research studies have reported successful metal stabilization by these mineral oxides, such as aluminium oxides (Hovsepyan and Bonzongo 2009), ferric oxides (Komárek et al. 2013) and manganese oxides (Zaman et al. 2009). Besides, the carbonized organic components of biochars accommodate a range of functional groups for metal species in the solution (Tong et al. 2011; Rees et al. 2014). Both carbonized organic components and inorganic mineral oxides should be considered for metal immobilization by SDBC (Qian and Chen 2013), where heterogeneous sorption mechanisms may occur depending on multiple surface properties and their association with pollutants.

The dual role of SDBC has been illustrated in recent studies (Qian and Chen 2013; Lu et al. 2012), and SDBC can serve as an effective dual sorbent for cationic metals $\left(\mathrm{Pb}^{2+}\right.$, Zhang et al. 2013), oxyanions $\left(\mathrm{CrO}_{4}{ }^{2-}, \mathrm{AsO}_{2}{ }^{-}\right.$, Zhang et al. 2015), as well as organic pesticides (Zhang et al. 2015; Tan et al. 2015). However, the individual roles of mineral oxides and carbonized organic compartments are not elucidated; in particular, their corresponding sorption kinetics and dependence on environmental conditions are yet to be figured out. Therefore, activated carbons (AC) and active aluminium oxides $\left(\mathrm{Al}_{2} \mathrm{O}_{3}\right)$ were selected as the representative carbonized organic compartment and mineral oxide, respectively, on which $\mathrm{Pb}$ and/or $\mathrm{Zn}$ sorption was compared to those on SDBC to identify the underlying mechanisms.

In addition, previous studies found that ageing processes may have a significant influence on the metal sorption behaviour (Eick et al. 1999; Ford et al. 1999). The ageing process after sorption can strengthen metal bonding via microporous diffusion, incorporation induced by re-crystallization, and formation and stabilization of surface precipitates (Rorff et al. 2006). As a result, when applying the SDBC for soil fixation, the ageing process may facilitate the metal immobilization. Therefore, the influence of ageing process on metal sorption on SDBC as well as $\mathrm{AC}$ and $\mathrm{Al}_{2} \mathrm{O}_{3}$ was also investigated, with a focus on the sorption capacity and bonding strength.

\section{Materials and methods}

Aluminium oxide, activated carbon, and sludgederived biochar

Active aluminium oxide $\left(\mathrm{Al}_{2} \mathrm{O}_{3}, \mathrm{HPLC}\right.$ grade $)$ and activated carbon (AC) were bought from Sinopharm Chemical Reagent Ltd Co (Shanghai, China), and their properties are summarized in Table 1 . The SDBC used 
herein was prepared in an LTKC-6-12 pipe oven (Lantian Instrument limited Corp., Hangzhou, China), full of $\mathrm{N}_{2}$ at a rate of $5 \mathrm{~m}^{3} \mathrm{~h}^{-1}$ to ensure inert conditions. Sequentially, the temperature in the pipe oven rose up to $400{ }^{\circ} \mathrm{C}$ at a rate of $20{ }^{\circ} \mathrm{C} \mathrm{min}-1$ and then maintained for $2 \mathrm{~h}$, which are the optimal conditions for pyrolyzing the dewatered sewage sludge into biochar based on our previous study (Zhang et al. 2013). The used sewage sludge was collected from Lijiao Sewage Treatment Plant in Guangzhou $\left(23^{\circ} 20^{\prime} \mathrm{N}, 113^{\circ} 30^{\prime} \mathrm{E}\right)$, where an oxidation ditch process with an average hydraulic retention time of $18 \mathrm{~h}$ was employed to remove $\mathrm{BOD}_{5}$, nitrogen, and phosphorus nutrients without the primary sedimentation process. The details on the sludge pyrolysis and properties of SDBC were given in our previous studies (Zhang et al. 2013, 2015), and the major properties of SDBC are indicated in Table 1. Based on the contents of $\mathrm{Al}$ and TOC of SDBC, a mixture of $\mathrm{Al}_{2} \mathrm{O}_{3}$ and $\mathrm{AC}$ (6:4 by mass) was also used to simulate the SDBC behaviour.

\section{Metal sorption experiments}

Batch sorption experiments were conducted by mixing $0.1 \mathrm{~g}$ of (1) SDBC, (2) AC, (3) $\mathrm{Al}_{2} \mathrm{O}_{3}$, and (4) mixture of $\mathrm{AC}$ and $\mathrm{Al}_{2} \mathrm{O}_{3}$, respectively, with $25 \mathrm{~mL}$ of solutions containing various amounts of $\mathrm{Pb}\left(\mathrm{NO}_{3}\right)_{2}$ or $\mathrm{Zn}\left(\mathrm{NO}_{3}\right)_{2}\left(0.01-0.5 \mathrm{mmol} \mathrm{L}{ }^{-1}\right)$ on a $160 \mathrm{rpm}$ shaker at 25 or $45^{\circ} \mathrm{C}$ for $24 \mathrm{~h}$. The solution $\mathrm{pH}$ was recorded, and the suspension was filtered with $0.45-\mu \mathrm{m}$ poresize PES disposable filters (Jinteng, China). The filtrate was acidified to $\mathrm{pH}<2$ and stored at $4{ }^{\circ} \mathrm{C}$. The concentrations of dissolved metals were determined by Optima 3000 XL inductively coupled plasmaatomic emission spectrometer (PerkinElmer, USA), based on Method 6010C of USEPA SW-846.

The residual sorbents were subject to further characterization. X-ray photoelectron spectroscopic (XPS) spectra were obtained via scanning the SDBC with an ESCALAB 250 X-ray photoelectron spectroscopy (Thermo-VG Scientific, USA). The existence and crystalline form of chemical precipitates on the sorbent surfaces after sorption were identified using Empyrean X-ray powder diffractometer (XRD) (PANalytical B.V., Holland) equipped with a $\mathrm{Cu} \mathrm{K \alpha}$ radiation source worked at $40 \mathrm{kV}$ and $40 \mathrm{~mA}$. The surface structure of the SDBC before and after sorption was analysed by scanning electron microscopy (SEM S-520, Hitachi, Japan) and electron dispersive X-ray analysis (EDX system, INCA 300, Oxford, UK). The EDX system was coupled with SEM using mixed BSE (back scatter electron) combined with LSE (lateral secondary electron) signal detector.

To probe the influence of ageing time on metal immobilization by SDBC, additional batch sorption experiments were conducted, where $0.25 \mu \mathrm{mol} \mathrm{L}{ }^{-1}$ $\mathrm{Pb}$ and/or $\mathrm{Zn}$ solutions were used with the four sorbents for $24 \mathrm{~h}$ at $25^{\circ} \mathrm{C}$ with the above-mentioned sorption procedure. Solution was separated by centrifugation and filtration with $0.45-\mu \mathrm{m}$ filter paper, and the resulting $\mathrm{Pb}$ or $\mathrm{Zn}$-loaded sorbents were exposed to ambient air at room temperature for 1-30 days. These artificially "aged" sorbents were then put again into contact with $0.25 \mu \mathrm{mol} \mathrm{L}{ }^{-1} \mathrm{~Pb}$ and/or $\mathrm{Zn}$ solution following the above procedure. The sorption capacity of aged sorbents was calculated from the remaining metal concentration in solution and compared to those

Table 1 Properties of different sorbents

\begin{tabular}{llll}
\hline Sorbents & Sludge-derived biochar (SDBC) & Activated carbon (AC) & ${\mathrm{Aluminium} \mathrm{oxide}\left(\mathrm{Al}_{2} \mathrm{O}_{3}^{\prime}\right.}^{\circ}$ \\
\hline $\mathrm{pH}(1: 10$ in DI water) & $7.39 \pm 0.08$ & $6.85 \pm 0.05$ & $7.31 \pm 0.03$ \\
BET specific surface $\left(\mathrm{m}^{2} \mathrm{~g}^{-1}\right)$ & 34.0 & 1263 & 147.1 \\
Elemental content $\left(\mathrm{mg} \mathrm{kg}^{-1}\right)$ & & $5808 \pm 2134$ & $559 \pm 69$ \\
$\mathrm{Al}$ & $74,252 \pm 532$ & & Not applicable \\
$\mathrm{Fe}$ & $36,400 \pm 632$ & 0.201 & \\
Organic functional groups $\left(\mathrm{mmol} \mathrm{g}^{-1}\right)$ & 0.285 & \\
Phenolic/hydroxyl & 0.175 & 0.112 & \\
Carboxyl & 0.310 & 0.045 & \\
Lactones & &
\end{tabular}


of fresh sorbents. All experiments were performed in triplicate.

The associations of $\mathrm{Pb}$ and $\mathrm{Zn}$ to both fresh and aged sorbents were characterized by traditional sequential extraction scheme (Tessier et al. 1979), categorizing into five fractions: (1) cation-exchangeable, (2) acid extractable, (3) reducible, (4) oxidizable, and (5) residual fractions. The details of the extraction procedures are given in our previous studies (Zhang et al. 2010).

\section{Results}

$\mathrm{Pb}$ and $\mathrm{Zn}$ sorption onto different sorbents

Sorption isotherms of single-metal solutions at $25^{\circ} \mathrm{C}$ fitted with Freundlich equation are presented in Fig. 1. Table 2 lists the corresponding sorbed amounts on different sorbents for comparison when the initial $[\mathrm{Pb}]$ or $[\mathrm{Zn}]$ was fixed at $250 \mu \mathrm{mol} \mathrm{L}{ }^{-1}$. The $\mathrm{Pb}$ sorption capacity was consistently higher than the corresponding $\mathrm{Zn}$ sorption capacity for each tested sorbent (SDBC, $\mathrm{AC}, \mathrm{Al}_{2} \mathrm{O}_{3}$, and $\mathrm{AC}+\mathrm{Al}_{2} \mathrm{O}_{3}$ ), especially for $\mathrm{AC}$. The $\mathrm{Pb}$ sorption followed the decreasing order of affinity: $\mathrm{AC}>\mathrm{AC}+\mathrm{Al}_{2} \mathrm{O}_{3}>\mathrm{SDBC}>\mathrm{Al}_{2} \mathrm{O}_{3}$. Yet, the $\mathrm{Zn}$ sorption showed a different order of affinity: $\mathrm{AC}+\mathrm{Al}_{2} \mathrm{O}_{3}>\mathrm{SDBC}>\mathrm{Al}_{2} \mathrm{O}_{3}>\mathrm{AC}$. The sorption capacity of SDBC for both metals was in between those of the mixture of $\mathrm{AC}+\mathrm{Al}_{2} \mathrm{O}_{3}$ and $\mathrm{Al}_{2} \mathrm{O}_{3}$ alone.

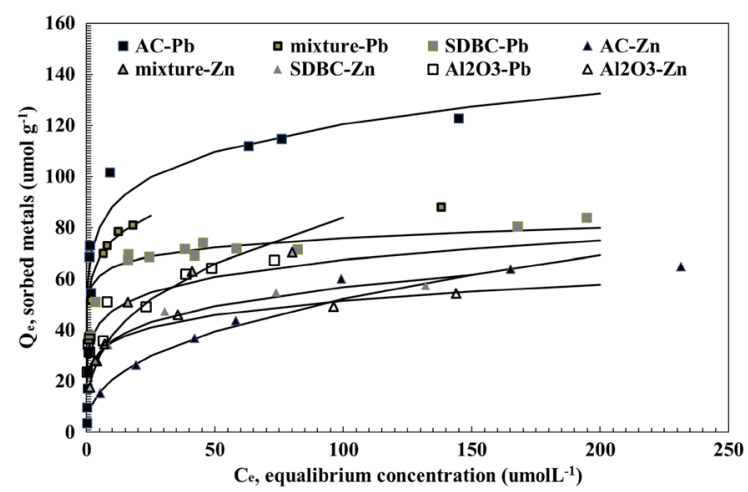

Fig. $1 \mathrm{~Pb}$ and $\mathrm{Zn}$ sorption isotherms at $25{ }^{\circ} \mathrm{C}$ in single-metal solutions on: (a) $\mathrm{AC}(0.05 \mathrm{~g}$ in $50 \mathrm{~mL})$, (b) amorphous $\mathrm{Al}_{2} \mathrm{O}_{3}$ $(0.1 \mathrm{~g}$ in $50 \mathrm{~mL})$, (c) mixture of $\mathrm{AC}$ and $\mathrm{Al}_{2} \mathrm{O}_{3}$ (4:6 by mass, $0.1 \mathrm{~g}$ in $50 \mathrm{~mL}$ ), and (d) SDBC $(0.1 \mathrm{~g}$ in $50 \mathrm{~mL}$ ) (better fitted by Freudlich equation as shown)
Our preliminary study did not found any detectable $\mathrm{Al}$ in the solution in contact with $\mathrm{Al}_{2} \mathrm{O}_{3}$ containing sorbents (data not shown), eliminating the possibility of $\mathrm{Al}_{2} \mathrm{O}_{3}$ dissolution and resorption on $\mathrm{AC}$ surface. In contrast, SEM image indicated that some $\mathrm{Al}_{2} \mathrm{O}_{3}$ colloids entered the micropores of $\mathrm{AC}$ (as illustrated in the supplementary materials, Fig. S1).

Temperature and metal competition

The results of sorption kinetics at 25 and $45{ }^{\circ} \mathrm{C}$ in single-metal and binary-metal solutions of $\mathrm{Pb}$ and $\mathrm{Zn}$ are presented in Fig. 2. Higher sorption capacities of SDBC and $\mathrm{AC}$ were reached at $45^{\circ} \mathrm{C}$ than $25^{\circ} \mathrm{C}$. However, for $\mathrm{Al}_{2} \mathrm{O}_{3}$, higher sorption capacities were observed at $25{ }^{\circ} \mathrm{C}$ instead of $45^{\circ} \mathrm{C}$ in both singlemetal and binary-metal solutions. For the mixture $\mathrm{AC}+\mathrm{Al}_{2} \mathrm{O}_{3}$, there was no difference in sorption at 25 and $45{ }^{\circ} \mathrm{C}$ except for $\mathrm{Zn}$ sorption in single-metal solution which was higher at $45{ }^{\circ} \mathrm{C}$ than $25{ }^{\circ} \mathrm{C}$.

In the sorption isotherms, $\mathrm{Pb}$ sorption was consistently higher than $\mathrm{Zn}$ sorption, but on SDBC, sorption capacity of $\mathrm{Zn}$ was comparable to that of $\mathrm{Pb}$ at $45{ }^{\circ} \mathrm{C}$ in single-metal solutions. There were higher sorption capacities in single-metal solutions compared to binary-metal solutions. In particular, $\mathrm{Zn}$ sorption was decreased by up to 10 times in the presence of $\mathrm{Pb}$, while $\mathrm{Pb}$ sorption was only decreased by $10-30 \%$ in the presence of $\mathrm{Zn}$.

\section{Artificial ageing}

Additional amounts of $\mathrm{Pb}$ and $\mathrm{Zn}$ were immobilized on the different sorbents following the ageing process (Fig. 3), with the exception of Zn sorption in binarymetal solutions on AC. The longer the ageing time was, the larger additional amounts of $\mathrm{Pb}$ and $\mathrm{Zn}$ were sorbed on $\mathrm{Al}_{2} \mathrm{O}_{3}$ and SDBC. However, there was no conclusive effect of ageing time on $\mathrm{AC}$ and $\mathrm{AC}+\mathrm{Al}_{2} \mathrm{O}_{3}$. In particular, a higher amount of $\mathrm{Zn}$ was sorbed on $\mathrm{AC}+\mathrm{Al}_{2} \mathrm{O}_{3}$ compared to $\mathrm{SDBC}$ at a shorter ageing time, but sorption on SDBC became greater than $\mathrm{AC}+\mathrm{Al}_{2} \mathrm{O}_{3}$ after 30-day ageing.

Sequential extraction results of $\mathrm{AC}, \mathrm{Al}_{2} \mathrm{O}_{3}$, and SDBC before and after 30-day ageing are shown in Fig. 4. For AC, Zn was largely present in the cationexchangeable fraction and the reducible fraction, while $\mathrm{Pb}$ was mainly found in the oxidizable fraction. For $\mathrm{Al}_{2} \mathrm{O}_{3}$, more than $95 \%$ of $\mathrm{Zn}$ sorption was 
Table 2 Sorbed amounts of $\mathrm{Pb}$ and $\mathrm{Zn}$ on different sorbents

a Calculated by

(1) $\times 0.6+(2) \times 0.4$, where initial $[\mathrm{Pb}]$ or $[\mathrm{Zn}]$ was fixed at $250 \mu \mathrm{mol} \mathrm{L}{ }^{-1}$

\begin{tabular}{lllrlrll}
\hline System & Metal & Temp $\left({ }^{\circ} \mathrm{C}\right)$ & \multicolumn{5}{l}{ Amount of sorbed metals $\left(\mu \mathrm{mol} \mathrm{g}^{-1}\right)$} \\
\cline { 3 - 7 } & & & $\mathrm{SDBC}$ & $\mathrm{Al}_{2} \mathrm{O}_{3}(1)$ & $\mathrm{AC}(2)$ & $\mathrm{AC}+\mathrm{Al}_{2} \mathrm{O}_{3}$ & Combination $^{\mathrm{a}}$ \\
\hline Single-metal & $\mathrm{Pb}$ & 25 & 75.08 & 54.00 & 117.11 & 79.94 & 91.86 \\
& $\mathrm{~Pb}$ & 45 & 82.10 & 65.96 & 106.18 & 80.52 & 90.09 \\
& $\mathrm{Zn}$ & 25 & 48.17 & 34.26 & 49.58 & 61.96 & 43.45 \\
& $\mathrm{Zn}$ & 45 & 79.81 & 59.35 & 43.67 & 80.97 & 49.94 \\
Binary-metal & $\mathrm{Pb}$ & 25 & 50.58 & 48.52 & 109.87 & 64.23 & 85.33 \\
& $\mathrm{~Pb}$ & 45 & 65.10 & 55.40 & 96.71 & 62.77 & 80.19 \\
& $\mathrm{Zn}$ & 25 & 7.15 & 7.83 & 10.71 & 12.28 & 9.56 \\
& $\mathrm{Zn}$ & 45 & 10.53 & 27.29 & 9.10 & 11.54 & 16.37 \\
\hline
\end{tabular}

(a) Sorption on activated carbon (AC)

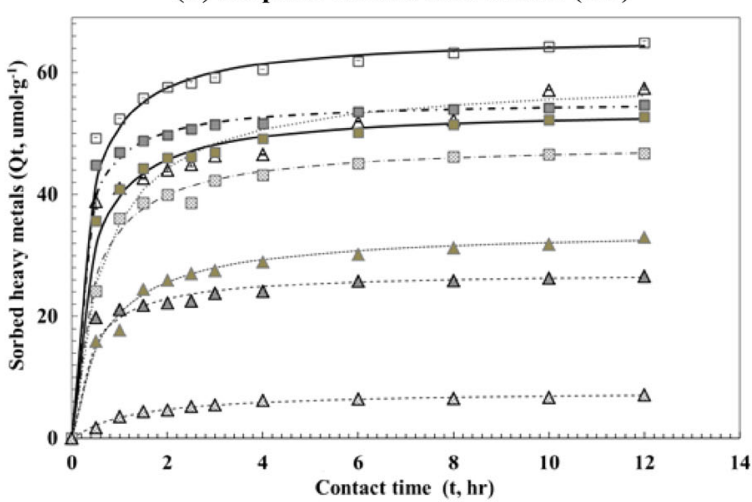

(c) Sorption on mixture 4:6 $\left(\mathrm{AC}+\mathrm{Al}_{2} \mathrm{O}_{3}\right)$

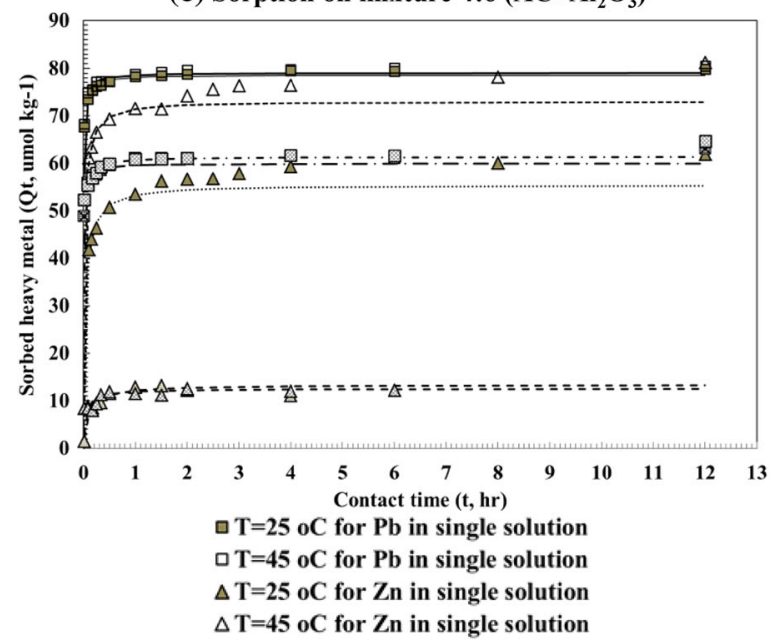

Fig. $2 \mathrm{~Pb}$ and $\mathrm{Zn}$ sorption kinetics at 25 and $45^{\circ} \mathrm{C}$ fitted with second-order kinetic model on: a $\mathrm{AC}(0.05 \mathrm{~g}$ in $50 \mathrm{~mL})$, b amorphous $\mathrm{Al}_{2} \mathrm{O}_{3}(0.1 \mathrm{~g}$ in $50 \mathrm{~mL})$, c mixture of $\mathrm{AC}$ and

correlated with the reducible fraction, whereas $\mathrm{Pb}$ in the acid extractable fraction and the oxidizable fraction were equal or higher than the reducible (b) Sorption on aluminium oxides $\left(\mathrm{Al}_{2} \mathrm{O}_{3}\right)$

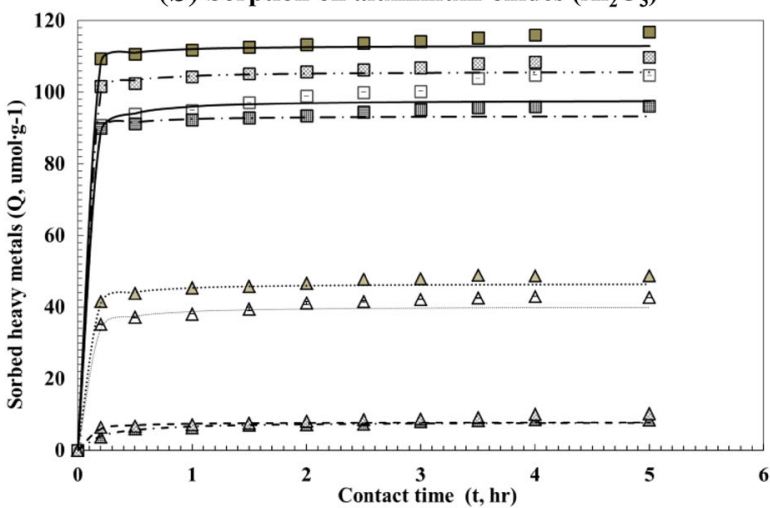

(d) Sorption on sludge derived biochar (SDBC)

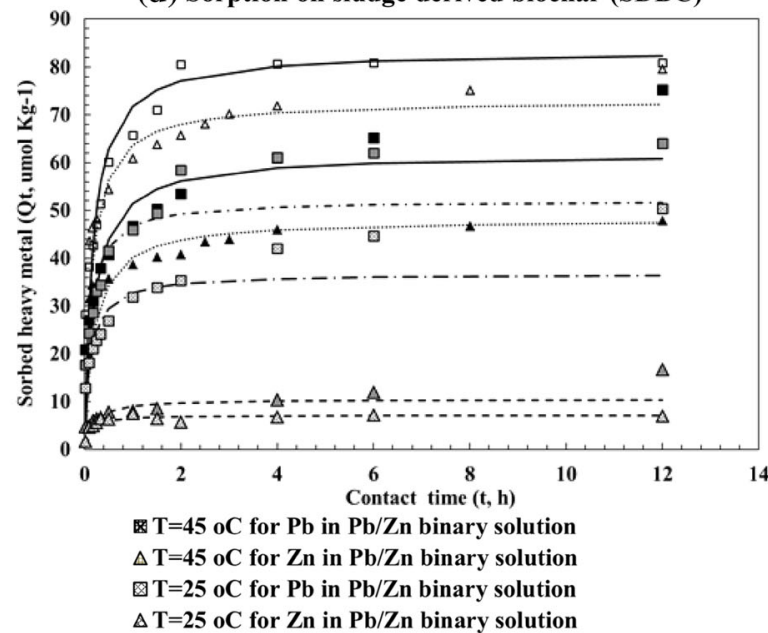

$\mathrm{Al}_{2} \mathrm{O}_{3}$ (4:6 by mass, $0.1 \mathrm{~g}$ in $50 \mathrm{~mL}$ ), and $\mathbf{d} \operatorname{SDBC}(0.1 \mathrm{~g}$ in $50 \mathrm{~mL}$ ) (initial $[\mathrm{Pb}(\mathrm{II})]$ and $[\mathrm{Zn}(\mathrm{II})]$ were $0.25 \mathrm{mM}$ in both single- and binary-metal solutions)

fraction. For SDBC, oxidizable and residual fractions represented more than $75 \%$ of the $\mathrm{Pb}$ sorption while the cation-exchangeable, acid extractable, and 
(a) Sorption of $\mathrm{Pb}$ on activated carbon (AC)

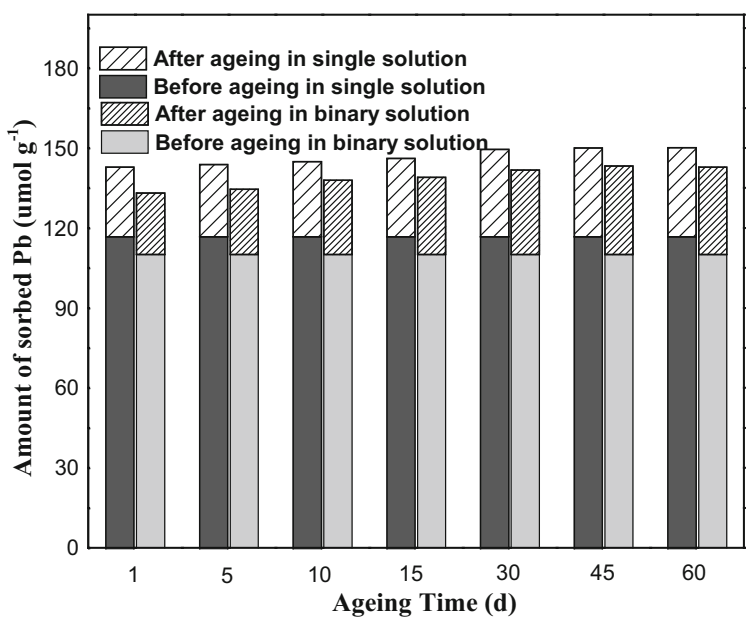

(c) Sorption of $\mathrm{Pb}$ on aluminium oxides $\left(\mathrm{Al}_{2} \mathrm{O}_{3}\right)$

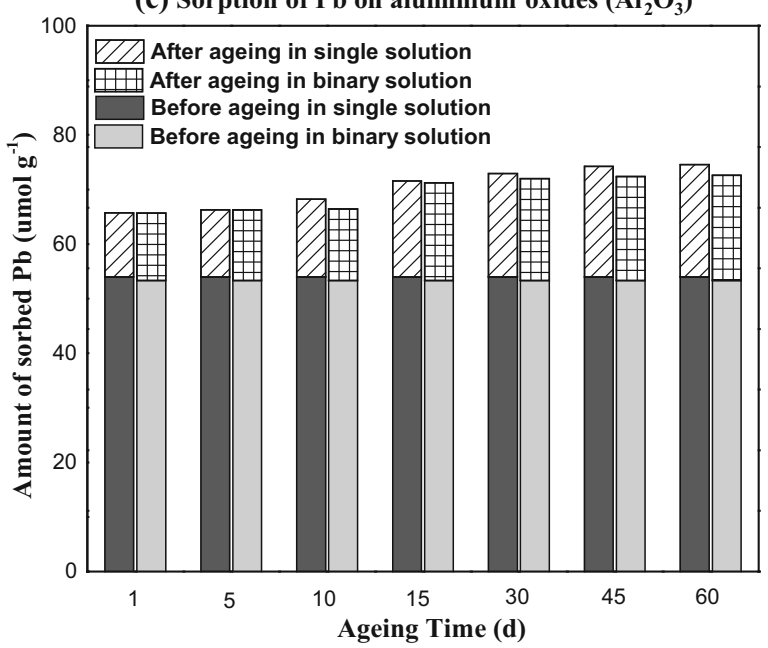

(e) Sorption of $\mathrm{Pb}$ on $\mathrm{SDBC}$ or on $\mathrm{AC}+\mathrm{Al}_{2} \mathrm{O}_{3}$

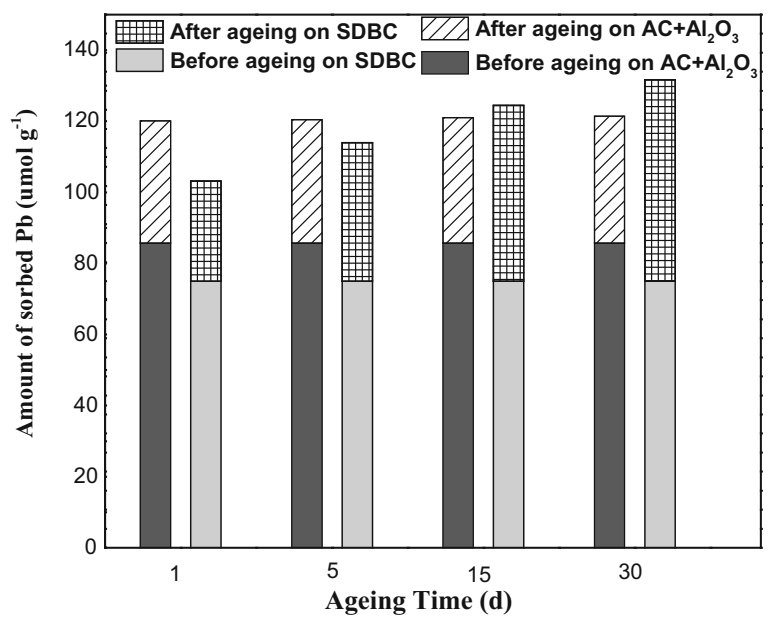

(b) Sorption of $\mathrm{Zn}$ on activated carbon (AC)

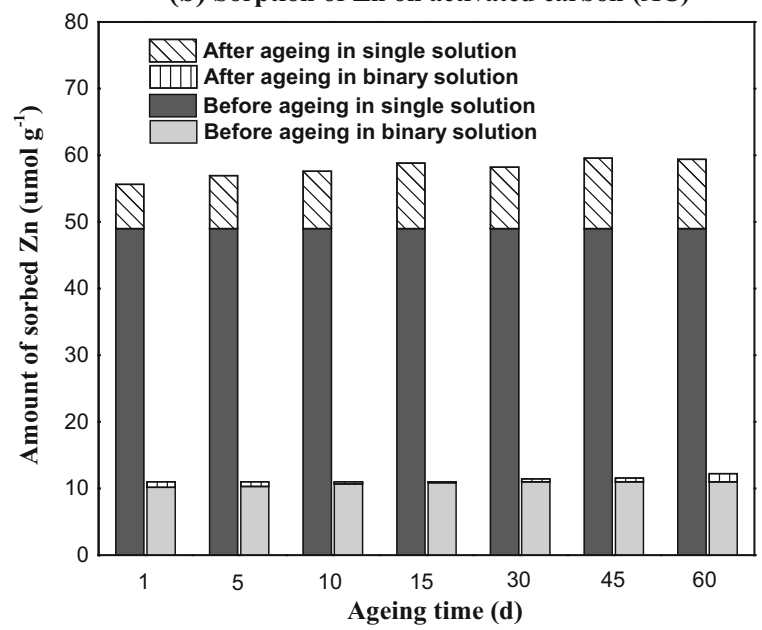

(d) Sorption of $\mathrm{Zn}$ on aluminium oxides $\left(\mathrm{Al}_{2} \mathrm{O}_{3}\right)$

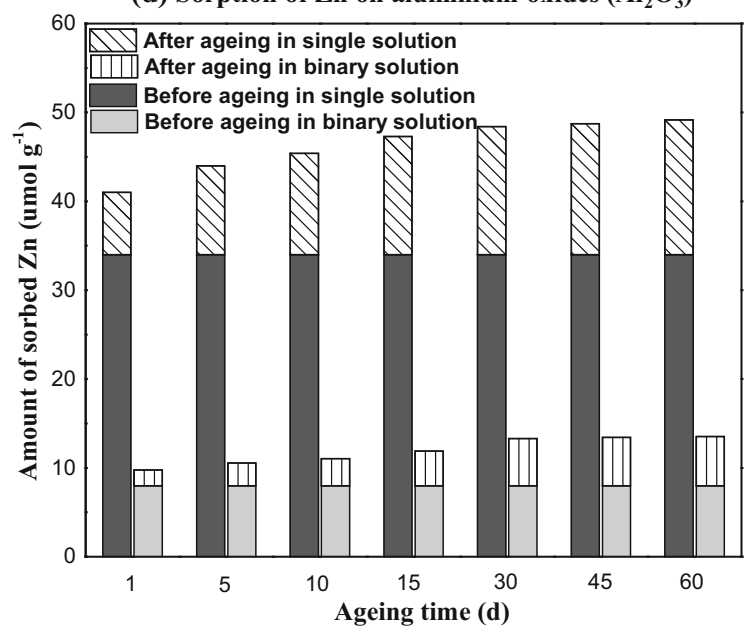

(f) Sorption of $\mathrm{Zn}$ on $\mathrm{SDBC}$ or on $\mathrm{AC}+\mathrm{Al}_{2} \mathrm{O}_{3}$

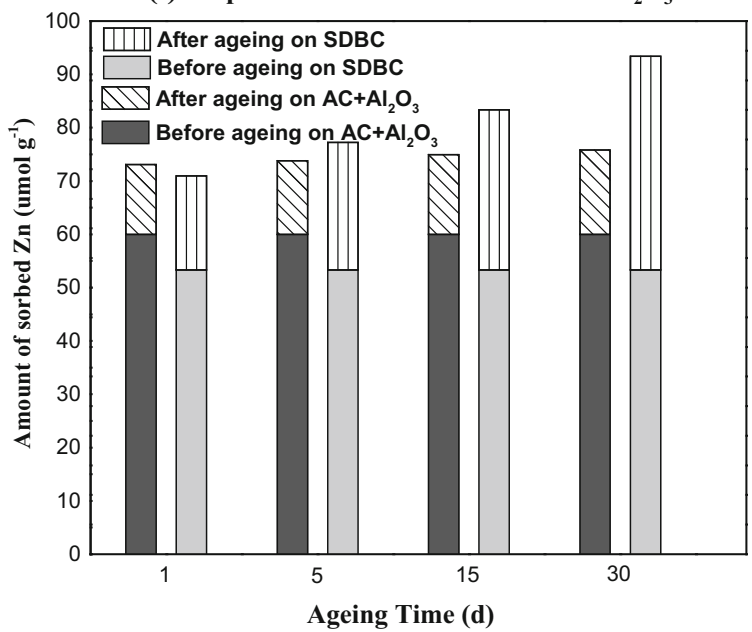


4Fig. 3 Metal sorption on different sorbents after varying artificial ageing time: a $\mathrm{Pb}$ sorption on $\mathrm{AC}(0.05 \mathrm{~g}$ in $50 \mathrm{~mL})$, b $\mathrm{Zn}$ sorption on $\mathrm{AC}(0.05 \mathrm{~g}$ in $50 \mathrm{~mL})$, c $\mathrm{Pb}$ sorption on amorphous $\mathrm{Al}_{2} \mathrm{O}_{3}(0.1 \mathrm{~g}$ in $50 \mathrm{~mL}), \mathbf{d ~ P b}$ sorption on amorphous $\mathrm{Al}_{2} \mathrm{O}_{3}(0.1 \mathrm{~g}$ in $50 \mathrm{~mL})$, e $\mathrm{Pb}$ sorption on mixture of $\mathrm{AC}$ and $\mathrm{Al}_{2} \mathrm{O}_{3}$ (4:6 by mass) and $\mathrm{SDBC}(0.1 \mathrm{~g}$ in $50 \mathrm{~mL})$, and $\mathbf{f} \mathrm{Pb}$ sorption on mixture of $\mathrm{AC}$ and $\mathrm{Al}_{2} \mathrm{O}_{3}$ (4:6 by mass) and SDBC $(0.1 \mathrm{~g}$ in $50 \mathrm{~mL})$ (Initial [Pb(II)] or [Zn(II)] was $0.25 \mathrm{mM}$ in all solutions)
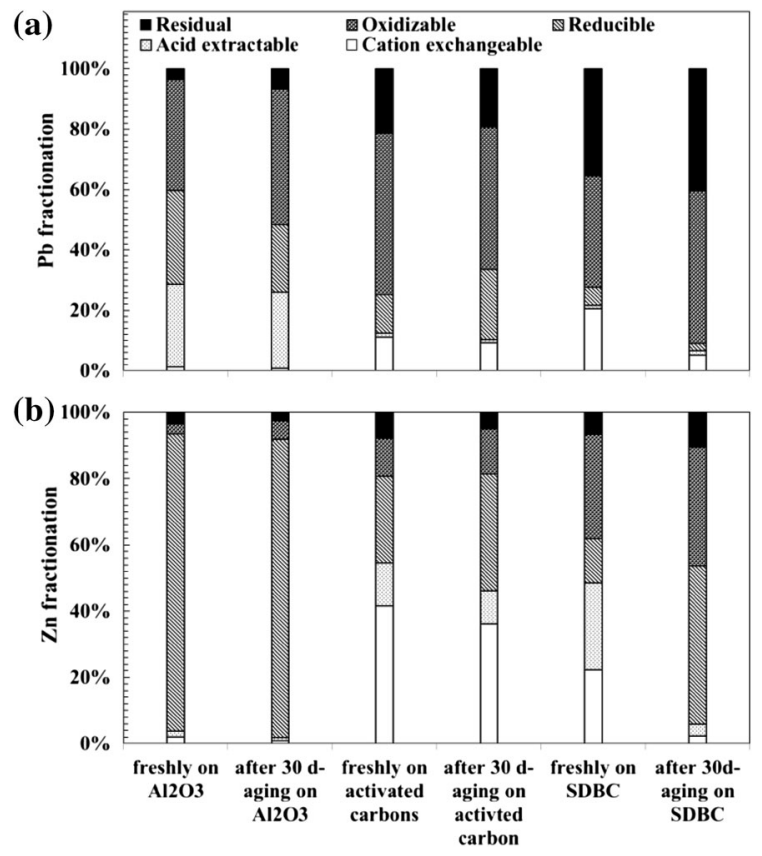

Fig. 4 Sequential extraction of $\mathrm{Pb}(\mathbf{a})$ and $\mathrm{Zn}$ (b) sorbed on $\mathrm{Al}_{2} \mathrm{O}_{3}$, AC, or SDBC, before or after 30-day ageing, respectively

oxidizable fractions accounted for the majority of $\mathrm{Zn}$ sorption.

It was found that 30-day ageing had no influence on the distribution of sorbed $\mathrm{Zn}$ on $\mathrm{Al}_{2} \mathrm{O}_{3}$, but resulted in a higher oxidizable fraction and a lower reducible fraction for sorbed $\mathrm{Pb}$. The opposite phenomenon was observed with 30-day ageing of $\mathrm{AC}$, where sorbed $\mathrm{Pb}$ was present as a higher reducible fraction and a lower oxidizable fraction but both the reducible and oxidizable $\mathrm{Zn}$ increased with less cation-exchangeable fraction. For SDBC, 30-day ageing increased the oxidizable and residual fractions of $\mathrm{Pb}$ and decreased the cation-exchangeable and reducible fractions. On the contrary, the reducible fraction of $\mathrm{Zn}$ sorbed on SDBC was considerably increased by ageing, while the cation-exchangeable fraction was reduced.
The XRD spectra (as illustrated in the supplementary materials, Fig. S2) proved the existence of crystalline $\mathrm{K}_{2} \mathrm{~Pb}\left(\mathrm{PO}_{3}\right)_{4}$ on the surface of Pb-loaded SDBC, but they were observed only after 30-day ageing. The XPS $\mathrm{O}_{1 \mathrm{~s}}$ spectra (Fig. 5) also showed that 30-day ageing resulted in a larger proportion of $\mathrm{M}-\mathrm{O}$ ( $\mathrm{Pb}$ : from 3.85 to $5.71 \%$; $\mathrm{Zn}$ : from 4.19 to $7.18 \%$ ), indicating the increased intensity or coverage of $\mathrm{Pb} / \mathrm{Zn}$ coordination with the oxygen-containing functional groups on the surface of SDBC.

\section{Discussion}

Competitive sorption of $\mathrm{Pb}$ and $\mathrm{Zn}$

The sorption capacities of each material were higher for $\mathrm{Pb}$ than $\mathrm{Zn}$ (Fig. 1), which was also commonly observed with organic sorbents (Rees et al. 2014) and inorganic sorbents (Abdus-Salam and Bello 2015). The favourable sorption of $\mathrm{Pb}$ compared to $\mathrm{Zn}$ (Figs. 1,2) may be explained by the smaller hydrated ionic radius (4.0 vs. $4.3 \AA$ ) and the greater electronegativity of $\mathrm{Pb}$ (2.33 vs. 1.65). These would facilitate diffusion of $\mathrm{Pb}$ inside micropores and enhance its affinity for cation exchange and surface complexation (Lu and Xu 2009; Depci et al. 2012). In this study, the difference in sorbed amounts of $\mathrm{Pb}$ and $\mathrm{Zn}$ was greater for $\mathrm{AC}$ than $\mathrm{SDBC}$ and $\mathrm{Al}_{2} \mathrm{O}_{3}$ (Fig. 2), possibly reflecting the presence of micropores and non-selective sorption sites. Furthermore, the smaller difference at $45{ }^{\circ} \mathrm{C}$ than $25{ }^{\circ} \mathrm{C}$ suggested a greater importance of transport processes in AC and SDBC. It was because a higher temperature could accelerate diffusion processes and therefore curtail the preferential sorption of $\mathrm{Pb}$ over $\mathrm{Zn}$ due to its smaller size.

The $\mathrm{Zn}$ sorption (and $\mathrm{Pb}$ sorption to a lower extent) was diminished in the binary-metal solutions (Fig. 3), and some sorbed $\mathrm{Zn}$ on the aged sorbents was even released due to $\mathrm{Pb}$ competition when put in contact with binary-metal solutions again. Similar competitive effects were observed for $\mathrm{Pb}$ and $\mathrm{Zn}$ in multi-metal solutions (Mohan and Singh 2002; Tsang and Lo 2006; Depci et al. 2012; Rees et al. 2014). This illustrates metal competition for some commonly available sorption sites and electrostatic repulsion of metals with the same charge. The metal fractionation by sequential extraction (Fig. 4) reinforced that $\mathrm{Pb}$ was more strongly bound to the sorbents than $\mathrm{Zn}$, 

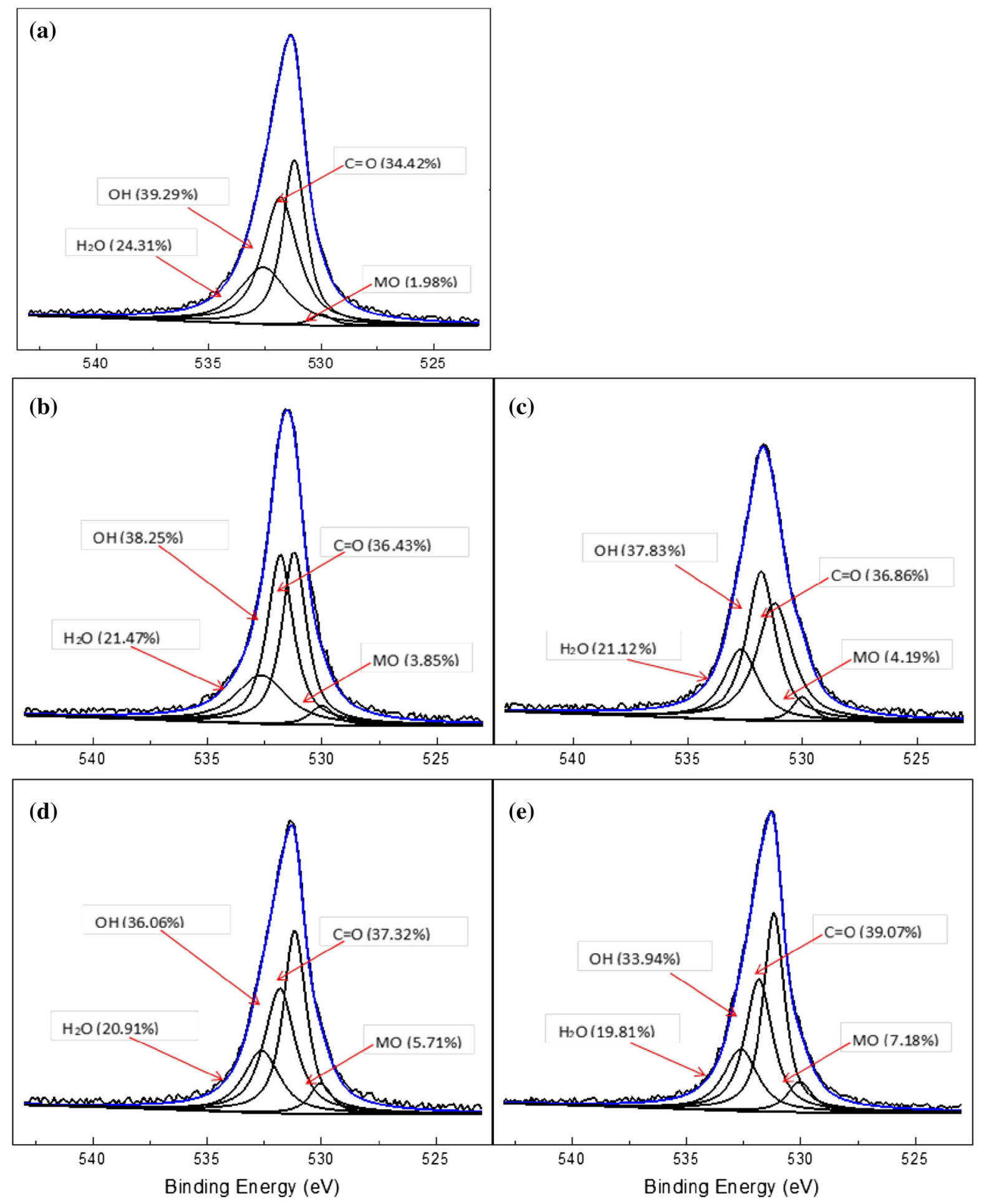

Fig. 5 XPS $\mathrm{O}_{1 \mathrm{~s}}$ spectra of SDBC with varying ageing time: a original SDBC, b freshly Pb-loaded, c Pb-loaded after 30-day ageing, d freshly Zn-loaded, and e Zn-loaded after 30-day ageing 
accounting for the greater suppression of $\mathrm{Zn}$ sorption by coexisting $\mathrm{Pb}$, but there was only a slight effect vice versa.

Comparison of SDBC with $\mathrm{AC}$ and $\mathrm{Al}_{2} \mathrm{O}_{3}$

The sorption characteristics of SDBC may resemble that of $\mathrm{Al}_{2} \mathrm{O}_{3}$ (i.e. model mineral sorbent) or that of $\mathrm{AC}$ (i.e. model organic sorbent). Despite the contrasting affinity of $\mathrm{Pb}$ and $\mathrm{Zn}$ for different sorbents, the observed sorption capacities of SDBC were more comparable to those of $\mathrm{Al}_{2} \mathrm{O}_{3}$ than $\mathrm{AC}$ (Figs. 2, 3). The competition of $\mathrm{Zn}$ by coexisting $\mathrm{Pb}$ was also much stronger for $\mathrm{SDBC}$ and $\mathrm{Al}_{2} \mathrm{O}_{3}$ than $\mathrm{AC}$, suggesting that the mineral components may present sorption sites (e.g. silanol and aluminol groups at the edge or corners) that are characterized by a higher affinity towards $\mathrm{Pb}$ than $\mathrm{Zn}$ due to difference in their ionic radii and charge densities. The results of sequential extraction (Fig. 4) showed that sorption of $\mathrm{Pb}$ and $\mathrm{Zn}$ on AC and SDBC took place in all fractions despite with different proportions, while sorption on $\mathrm{Al}_{2} \mathrm{O}_{3}$ was predominantly on reducible fraction corresponding to mineral oxides.

However, the influence of temperature on metal sorption on SDBC was more similar to that of AC than $\mathrm{Al}_{2} \mathrm{O}_{3}$ (Fig. 2). An increase in sorption with increasing temperature was seen for SDBC and AC, indicative of an endothermic sorption process (Hefne et al. 2008; Dandanmozd and Hosseinpur 2010). This may correspond to an increase in the kinetic energy or a better solvation of the metal ions (Naseem and Tahir 2001). Similar results of increased sorption capacity and enhanced sorption kinetics on $\mathrm{AC}$ at a higher temperature were also reported for $\mathrm{Pb}$ (Gueu et al. 2007) and $\mathrm{Zn}$ (Marzal et al. 1996). An increase in temperature could facilitate both chemical sorption reactions and physical diffusion processes in SDBC, in a way similar to those in AC. These results reveal that wellrecognized diversity of the surface active sites of SDBC plays different roles under varying environmental conditions, i.e. mineral oxides display a more selective sorption under metal competition, whereas carbonized organic compartments are governed by temperature-dependent diffusion processes.
Ageing of sorbed metals

With artificial ageing of metal-loaded SDBC in ambient air, a change was observed in the relative importance of sorption processes. The weaker interactions via cation exchange and coordination with phosphate on SDBC were transformed into crystalline metal precipitates such as $\mathrm{K}_{2} \mathrm{~Pb}\left(\mathrm{PO}_{3}\right)_{4}$ identified in the XRD spectra after 30-day ageing (as illustrated in the supplementary materials, Fig. S2), suggesting the formation of stronger bonding with mineral oxides and organic matter. This may also explain why ageing led to a higher sorption capacity for all sorbents of this study, particularly for SDBC (Fig. 3), as the transformation of sorbed metals into precipitates may empty previously occupied sorption sites and/or create new reactive surfaces for additional metal sorption from the solution.

In addition, ageing is often associated with the oxidation of biochar surfaces, resulting in a larger quantity of oxygen-containing functional groups that could also lead to a higher sorption capacity via surface complexation (Tsang et al. 2007; Guo et al. 2014). This was confirmed by the XPS spectra (Fig. 5) where the proportions of $\mathrm{Pb}-\mathrm{O}$ and $\mathrm{Zn}-\mathrm{O}$ increased with ageing. The sequential extraction (Fig. 4) also revealed a larger oxidizable fraction of $\mathrm{Pb}$ on SDBC. On the contrary, this was not observed on AC because the surfaces had already been fully oxidized by the activation process during production. Furthermore, the time-dependent diffusion of metals along the interior surfaces and/or within the small pores of SDBC over time may also contribute to a higher sorption capacity with ageing, although it could not be confirmed in this study.

These beneficial effects of ageing on metal sorption by SDBC implies that the metal immobilization observed in the short term in SDBC-amended soils would probably last longer and become more stable than its sorption capacity measured in batch experiments (Rees et al. 2014; Fang et al. 2016). The slowly releasing metals from contaminated soils may still be sorbed on SDBC over time, yet the resilience of long-term metal immobilization against continuous leaching and varying field conditions (e.g. pH, redox, biotic disturbance) should be further attested (Tsang et al. 2013; Fang et al. 2016). 


\section{Conclusions}

Pyrolyzing sludge into biochar is a potentially promising recycling/disposal option for the increasing production of municipal wastewater sludge, from which the sludge-derived biochar presents an excellent sorbent for soil amendment because of its abundant contents of carbonized organic and mineral components. This study reveals that sludge-derived biochar can be evaluated as a mixture of activated carbon and aluminium oxide for elucidating the roles of different compartments under different environmental conditions. In particular, sorption on organic compartment is more temperature-dependent due to diffusion processes, while sorption on mineral oxides is more selective under metal competition. Furthermore, ageing of metal-loaded biochar in ambient air results in metal-phosphate precipitation and provides additional sorption sites, implying a favourable long-term effect of SDBC for metal immobilization in soil amendment that requires future investigations.

Acknowledgments The authors wish to thank the National Natural Science Foundation of China (project no. 41272383), and Science and Technology Planning Project of Guangdong Province (2014A050503032) for the financial support of this study.

\section{References}

Abdus-Salam, N., \& Bello, M. O. (2015). Kinetics, thermodynamics and competitive adsorption of lead and zinc ions onto termite mound. International Journal Environmental Science and Technology, 12, 3417-3426.

Cao, X., \& Harris, W. (2010). Properties of dairy-manurederived biochar pertinent to its potential use in remediation. Bioresource technology, 101, 5222-5228.

Chen, B., Yuan, M., \& Qian, L. (2012). Enhanced bioremediation of PAH-contaminated soil by immobilized bacteria with plant residual and biochar as carriers. Journal of Soils and Sediments, 12, 1350-1359.

Dandanmozd, F., \& Hosseinpur, A. R. (2010). Thermodynamic parameters of zinc sorption in some calcareous soils. Journal of American Science, 6(7), 298-304.

Depci, T., Kul, A. R., \& Onal, Y. (2012). Competitive adsorption of lead and zinc from aqueous solution on activated carbon prepared from Van pulp: study in single- and multisolute systems. Chemical Engineering Journal, 200, 224-236.

Eick, M. J., Peak, J. D., Brady, P. V., \& Pesek, J. D. (1999). Kinetics of lead adsorption/desorption on goethite: Residence time effect. Soil Science, 164, 28-39.

Fang, S., Tsang, D. C. W., Zhou, F., Zhang, W. H., \& Qiu, R. L. (2016). Stabilization of cationic and anionic metal species in contaminated soils using sludge-derived biochar. Chemosphere, 149, 263-271.

Ford, R. G., Scheinost, A. C., Scheckel, K. G., \& Sparks, D. L. (1999). The link between clay mineral weathering and the stabilization of $\mathrm{Ni}$ surface precipitates. Environmental Science and Technology, 33, 3140-3144.

Gueu, S., Yao, B., Adouby, K., \& Ado, G. (2007). Kinetics and thermodynamics study of lead adsorption on to activated carbons from coconut and seed hull of the palm tree. International Journal Environmental Science and Technology, 4(1), 11-17.

Guo, Y., Tang, W., Wu, J., Huang, Z., \& Dai, J. (2014). Mechanism of $\mathrm{Cu}$ (II) adsorption inhibition on biochar by its aging process. Journal Environmental Science, 26, 2123-2130.

Hefne, J. A., Mekhemer, W. K., Alandis, N. M., Aldayel, O. A., \& Alajyan, T. (2008). Kinetic and thermodynamic study of the adsorption of $\mathrm{Pb}$ (II) from aqueous solution to the natural and treated bentonite. International Journal of Physical Sciences, 3(11), 281-288.

Hovsepyan, A., \& Bonzongo, J. C. J. (2009). Aluminum drinking water treatment residuals (Al-WTRs) as sorbent for mercury: implications for soil remediation. Journal of Hazardous Materials, 164, 73-80.

Inyang, M. I., Gao, B., Yao, Y., Xue, Y. W., Zimmerman, A., Mosa, A., et al. (2016). A review of biochar as a low-cost adsorbent for aqueous heavy metal removal. Critical Reviews in Environmental Science and Technology, 46(4), 406-433.

Komárek, M., Vanek, A., \& Ettler, V. (2013). Chemical stabilization of metals and arsenic in contaminated soils using oxides-a review. Environmental Pollution, 172, 9-22.

Kuppusamy, S., Thavamani, P., \& Megharaj, M. (2016). Agronomic and remedial benefits and risks of applying biochar to soil: Current knowledge and future research directions. Environmental International, 87, 1-12.

Liu, T., Liu, B., \& Zhang, W. (2014). Nutrient and heavy metals in biochar produced by sewage sludge pyrolysis: Its application in sol amendment. Polish Journal Environmental Study, 23, 271-275.

Lu, S. G., \& Xu, Q. F. (2009). Competitive adsorption of Cd, Cu, $\mathrm{Pb}$ and $\mathrm{Zn}$ by different soils of Eastern China. Environmental Geology, 57, 685-693.

Lu, H. L., Zhang, W. H., Yang, Y. X., Huang, X. F., Wang, S. Z., \& Qiu, R. L. (2012). Relative distribution of $\mathrm{Pb}^{2+}$ sorption mechanisms by sludge-derived biochar. Water Resource, 46, 854-862.

Marzal, P., Seco, A., \& Gabaldon, C. (1996). Cadmium and zinc adsorption onto activated carbon: influence of temperature, $\mathrm{pH}$ and metal/carbon ratio. Journal Chemical Technology and Biotechnology, 66, 279-285.

Mohan, D., \& Singh, K. P. (2002). Single- and Multi-component adsorption of cadmium and zinc using activated carbon derived from bagasse-an agricultural waste. Water Resource, 36, 2304-2318.

Naseem, R., \& Tahir, S. S. (2001). Removal of Pb(II) from aqueous/acidic solutions by using bentonite as an adsorbent. Water Research, 35(16), 3982-3986.

Qian, L., \& Chen, B. (2013). Dual role of biochars as adsorbents for aluminum: The effects of oxygen-containing organic 
components and the scattering of silicate particles. Environmental Science and Technology, 47, 8759-8768.

Rees, F., Simonnot, M. O., \& Morel, J. L. (2014). Short-term effects of biochar on soil heavy metal mobility are controlled by intra-particle diffusion and soil $\mathrm{pH}$ increase. European Journal Soil Science, 65, 149-161.

Rorff, A. A., Elzinga, E. J., Reeder, R. J., \& Fisher, N. S. (2006). The effect of aging and $\mathrm{pH}$ on $\mathrm{Pb}$ (II) sorption processes at the calcite-water interface. Environmental Science and Technology, 40, 1792-1798.

Song, X. D., Xue, X. Y., Chen, D. Z., He, P. J., \& Dai, X. H. (2014). Application of biochar from sewage sludge to plant cultivation: Influence of pyrolysis temperature and biochar-to-soil ratio on yield and heavy metal accumulation. Chemosphere, 109, 213-220.

Tan, X. F., Liu, Y. G., Zeng, G. M., Wang, X., Hu, X. J., Gu, Y. L., et al. (2015). The application of biochar for the removal of pollutants from aqueous solutions. Chemosphere, 125, 70-85.

Tessier, A., Campbell, P. G. C., \& Bisson, M. (1979). Sequential extraction procedure for the speciation of particulate trace metals. Analytical Chemistry, 51, 844-851.

Tong, X., Li, J., Yuan, J., \& Xu, R. (2011). Adsorption of Cu(II) by biochars generated from three crop straws. Chemical Engineering Journal, 172, 828-834.

Tsang, D. C. W., Hu, J., Liu, M. Y., Zhang, W., Lai, K. C. K., \& Lo, I. M. C. (2007). Activated carbon produced from waste wood pallets: Adsorption of three classes of dyes. Water, Air, and Soil pollution, 184, 141-155.
Tsang, D. C. W., \& Lo, I. M. C. (2006). Competitive $\mathrm{Cu}$ and Cd sorption and transport in soils: A combined batch kinetics, column and sequential extraction study. Environmental Science and Technology, 40, 6655-6661.

Tsang, D. C. W., Olds, W. E., Weber, P. A., \& Yip, A. C. K. (2013). Soil stabilisation using AMD sludge, compost and lignite: TCLP leachability and continuous acid leaching. Chemosphere, 93, 2839-2847.

Wesenbeeck, S. V., Prins, W., Ronsse, F., \& Antal, M. J., Jr. (2014). Sewage sludge carbonization for biochar applications: fate of heavy metals. Energy \& Fuels, 28, 5318-5326.

Zaman, M. I., Mustafa, S., Khan, S., \& Xing, B. (2009). Effect of phosphate complexation on $\mathrm{Cd}^{2+}$ sorption by manganese dioxide $(\beta-\mathrm{MnO} 2)$. Journal of Colloid Interface Science, 330, 9-19.

Zhang, W. H., Huang, H., Tan, F. F., Wang, H., \& Qiu, R. L. (2010). Influence of EDTA-washing on the species and mobility of heavy metals residual in soils. Journal of Hazardous Materials, 173, 369-376.

Zhang, W. H., Mao, S. Y., Chen, H., Huang, L., \& Qiu, R. L. (2013). Pb(II) and $\mathrm{Cr}(\mathrm{VI})$ sorption by biochars pyrolyzed from the municipal wastewater sludge under different heating conditions. Bioresource technology, 147, 545-552.

Zhang, W. H., Zheng, P., Zheng, J., Tsang, D. C. W., \& Qiu, R. L. (2015). Sludge-derived biochar for arsenic(III) immobilization: Effects of solution chemistry on sorption behavior. Journal of Environmental Quality, 44, 1119-1126. 